シリサイド系金属間化合物のメカニカルアロイングによる合成

小林 慶三, 三輪 謙治 通産省工業技術院名古屋工業技術研究所, T462 名古屋市北区平手町1-1.

\title{
Synthesis of Ti, Mo and W Silicide Intermetallic Compounds
} by Mechanical Alloying

Keizo Kobayashi and Kenji Miwa

National Industrial Research Institute of Nagoya, AIST, MITI, 1-1 Hirate-cho Kita-ku, Nagoya 462.

$\mathrm{Ti}_{5} \mathrm{Si}_{3}$ powder was synthesized by mechanical alloying (MA) of $\mathrm{Ti}$ powder and $\mathrm{Si}$ powder using a vibrational ball milling under $35 \mathrm{kPa}$ Ar. When stainless steel was used as a vessel and balls for MA, the obtained MA powder was amorphous and included a considerable amount of Fe because of adhesive wear of MA balls.

$\mathrm{ZrO}_{2}$ ball forms coating layer on the surface of a ball in MA process, so that the contamination from MA ball to MA powder can be reduced. The $\mathrm{Ti}_{5} \mathrm{Si}_{3}$ powder milled for $720 \mathrm{ksec}$ with $\mathrm{ZrO}_{2}$ balls was not amorphous and contained $\mathrm{Ti}$ and $\mathrm{Si}$ crystal phase. WSi ${ }_{2}$ powder and MoSi 2 powder were not synthesized by MA of $\mathrm{W}$ powder and Si powder or Mo powder and Si powder for $720 \mathrm{ksec}$ with $\mathrm{ZrO}_{2}$ balls.

\section{1 緒 言}

汌サド・系金属間化合物は，一般に融点が高いこと から高温蝺造用材料としての応用が期待される.し かし，高融点で活性な金属元素を多く含むため，溶 解による合成では耐火物 (るつぼなど)や溶解雾团気 との反応が考えられ，健全な合金を得ることは難し い.

一方，金属素粉末を出発原料として固相状態での

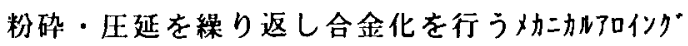

（以下MAと記す）では，溶解法で問題となるこれら の污染が少ない健全な合金粉末の得られる可能性が
ある ${ }^{12}$.

本研䒮では，Ti-Si合金を中心としたシリサイド系金 属間化合物をそれぞれの素粉末を出発原料としてMA 処理することにより合成し，生成相の同定を行った。 さらに，洲仆系金属間化合物のような高硬度材料 をMAする際のHAボーNからの污染について検討を行っ た.

\section{2 試料およひ寒験方法}

出発原料として Ti 粉末 (純度99\%) および $\mathrm{Si}$ 㸮末（純度99.99\%）をTi $\mathrm{Si}_{3}$ 組成になるように科量 
Table1 Chemical compositions and specific gravities of ceramic balls.

\begin{tabular}{ccc} 
ball & Composition(mass $\%$ ) & Specific gravity \\
\hline Mullite & $60 \% \mathrm{Al}_{2} \mathrm{O}_{3}-37 \% \mathrm{SiO}_{2}$ & 2.7 \\
$\mathrm{Al}_{2} \mathrm{O}_{3}-\mathrm{SiO}_{2}(\mathrm{HD})$ & $93 \% \mathrm{Al}_{2} \mathrm{O}_{3}-5 \% \mathrm{SiO}_{2}$ & 3.6 \\
$\mathrm{Al}_{2} \mathrm{O}_{3}$ & $99.5 \% \mathrm{Al}_{2} \mathrm{O}_{3}$ & 3.7 \\
$\mathrm{ZrO}_{2}$ & $93 \% \mathrm{ZrO}_{2}-5.5 \% \mathrm{CaO}$ & 5.3
\end{tabular}

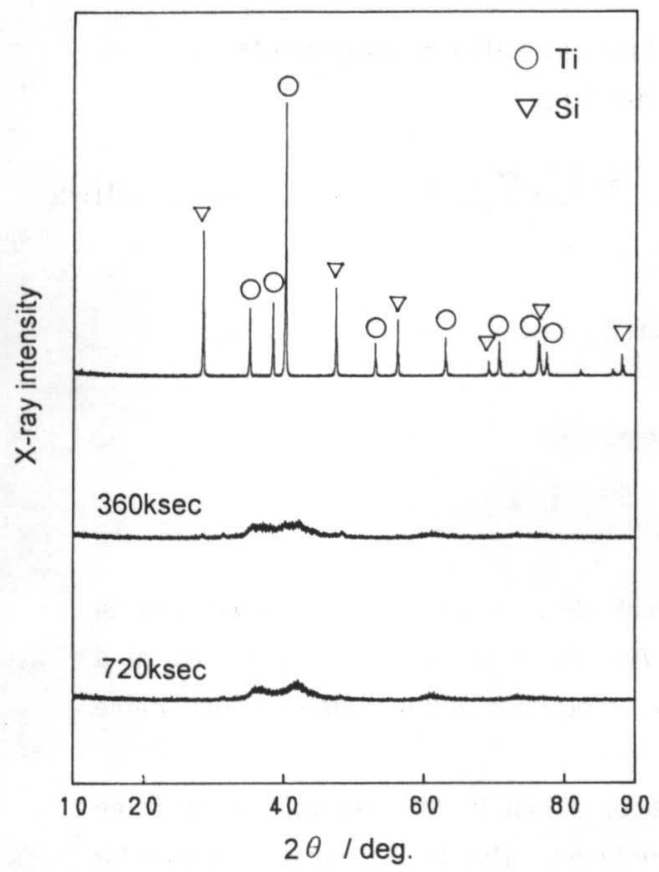

Fig.1 X-ray diffraction patterns of mechanicaly alloyed Ti-Si powders milled for various time.

し，乳鉢で予備混合をしたのちMA処理に供した，MA 処理は振動型ボールミル(日新技研製スーペーミスニ)を用い, 最長 $720 \mathrm{ksec}$ 間の処理を行った. 容器およびポールに はスデルス鋼(SUS304)製のものを用いた. MAに供した 粉末重量は, ボー川重量に対して0.06になるようにし た. MA中の雾囲気は $35 \mathrm{kPa}$ の減圧Ar雾囲気である. 汌井仆”系金属間化合物は硬度が高いため, 耐磨耗

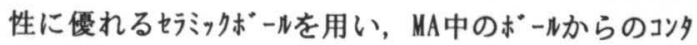

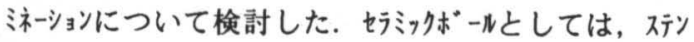

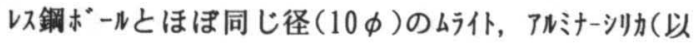
下HDと記す), アルミナ, ジルニアを用い, スデルス鎆ボールと 同数を容器にいれた。 それぞれのポールの組成および

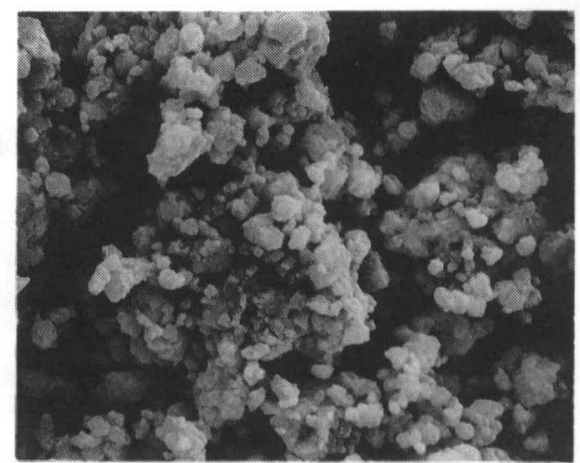

Fig.2 Microstructure of Ti-Si powder milled for $720 \mathrm{ksec}$ with SUS balls.

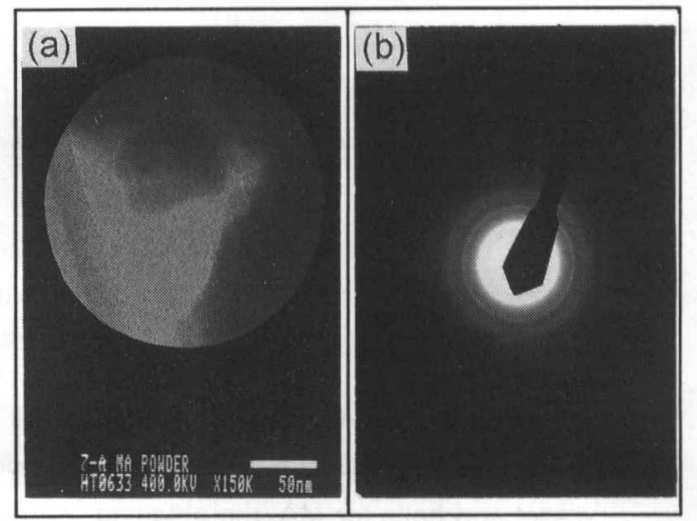

Fig.3 TEM microstructure(a) and electron diffraction pattern(b) of Ti-Si powder milled for $720 \mathrm{ksec}$ with SUS balls.

Table2 Chemical composition of Ti-Si powder milled for $720 \mathrm{ksec}$ with SUS balls.

(mass\%)

\begin{tabular}{ccccc} 
& $\mathrm{Si}$ & $\mathrm{Ti}$ & $\mathrm{Fe}$ & $\mathrm{Zr}$ \\
\hline Ti-Si MA powder & 26.1 & 71.8 & 2.1 & $<0.01$
\end{tabular}

比重はTable1の通りである. MAにより得られた粉末 のSEM観察, X線回折, 化学分析などを行った.

コンタタネーショの少ない条件で, Mo 粉末（純度99.5\%） あるいは | 粉末（純度99.9\%）にSi粉末をMoSi 2 組 成，WSi $2_{2}$ 組成になるよう配合し，720ksec間のMA処 理を行い, 得られた粉末の $X$ 線回折やSEM観察を行 った. 


\section{3 実験結果およひ考察}

\section{1 スデルス鋼ボールによるTi $5 S_{5} \mathrm{Si}_{3}$ の $\mathrm{HA}$ 合成}

TiおよびSiを出発原料としてMA処理した際のHA時 間の進行に伴う相変化をFig. 1に示す. 予備混合し た段階ではTiおよびSiのピークが観察されるが，100k sec間のMA処理によりブロードなX線回折ペターンとなる。 さらに岒時間を長くすると、ブロードな回折パターンの 中にわずかながら起伏が認められるようになる。

720ksecのMA処理により得られた粉末は，Fig. $2 に$ 示すように $1 \mu \mathrm{m}$ 程度の粉末となっているが，凝集 体も多く観察される。この粉末をTEMで観察してみ ると,Fig. 3-(a)のような粉末周辺部では電子回折 $n^{\circ}$ ターンがFig.3-(b)のように氺なパターンとなっている. しかし，粉末内部では結晶相らしき轧恬観察さ れる.X線回折結果とあわせて考察すると， $\mathrm{Ti}_{5} \mathrm{Si}_{3}$ 組成のTiおよびSiの菜粉末をMA処理した場合、はじ めに顺状の粉末が得られるが，さらにMAするこ とにより粉末内部で合金化が進行するものと考えら れる。この肘枌末を真空中で1773Kで1.2ksec間保持 すると，構成㕲は $\mathrm{Ti}_{5} \mathrm{Si}_{3}$ の結晶相へと変化する。 た だ，粉末自体が活性であるため，熱処理後の試料は 窒化物や酸化物を含んでいるようである

得られたMA粉末を化学分析してみると，Table2に 示すようにFeのコッタミネンショが多いことがわかる，MA 処理後に容器内面よりボール表面の方が凸凹になって いることから，Feの混入源としてはボーNの磨耗が考 えられる゙リ

\section{2 七ララフクスボールによるTi $5 \mathrm{Si}_{3}$ のHA合成}

ステンレス鋼ボールを用いてTis ${ }_{5} \mathrm{Si}_{3}$ 組成のTiおよびSiの 素粉末をMA合成した場合，TiとSi とのMA反応でなく Feのコンタミネーショルによりアモれフス化が助長された可能性 がある、そこで，Feのコタタミネションを抑えたMA処理を

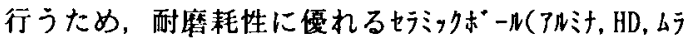
仆、ジルニア）を用いたMA処理を行った．実験条件はス对 ル人䞒製ボールを用いた場合と同様である。720ksecの MA処理後のそれぞれの粉末のX線回折パタ-ンをFig. 4 に示す．スデルス鎆ボー川の場合と異なり，いずれの壮 㸮末とも720ksec䦎のHA処理後でも，TiやSiの結晶 相のピークが観察される．X線回折ペターシからみたMA

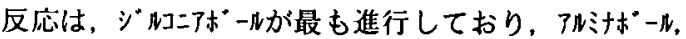
HDボール,ムライトボ゚ールの順になっている。これは用いたお゙ 一川の比重の順序になっており，重いボールを用いた方

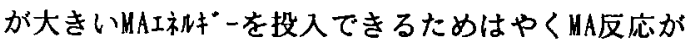
進行したものと考えられる，それぞれの胜枌末は旷

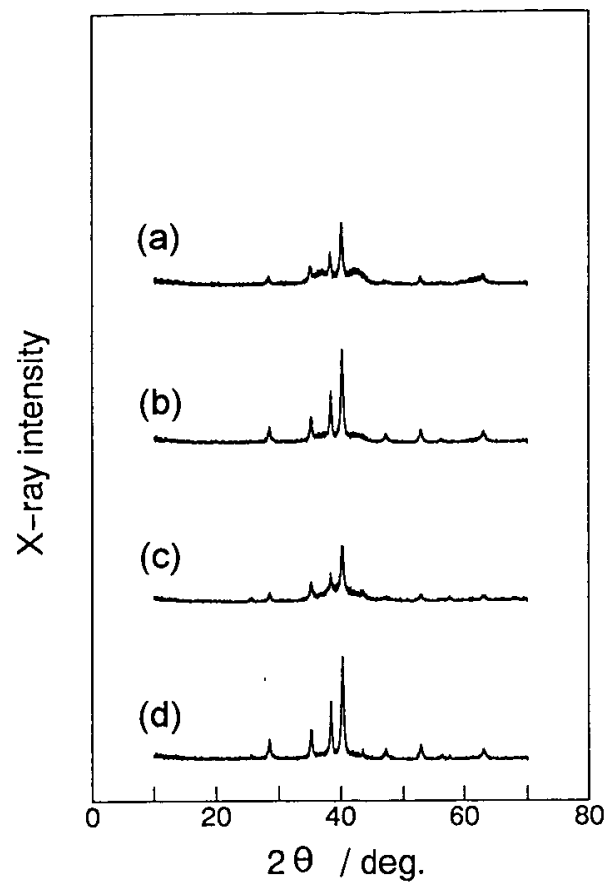

Fig.4 X-ray diffraction patterns of Ti-Si powders milled for $720 \mathrm{ksec}$ with various balls. (a) $\mathrm{ZrO}_{2}$ balls,(b) $\mathrm{HD}$ balls,(c) $\mathrm{Al}_{2} \mathrm{O}_{3}$ balls and (d)Mullite balls

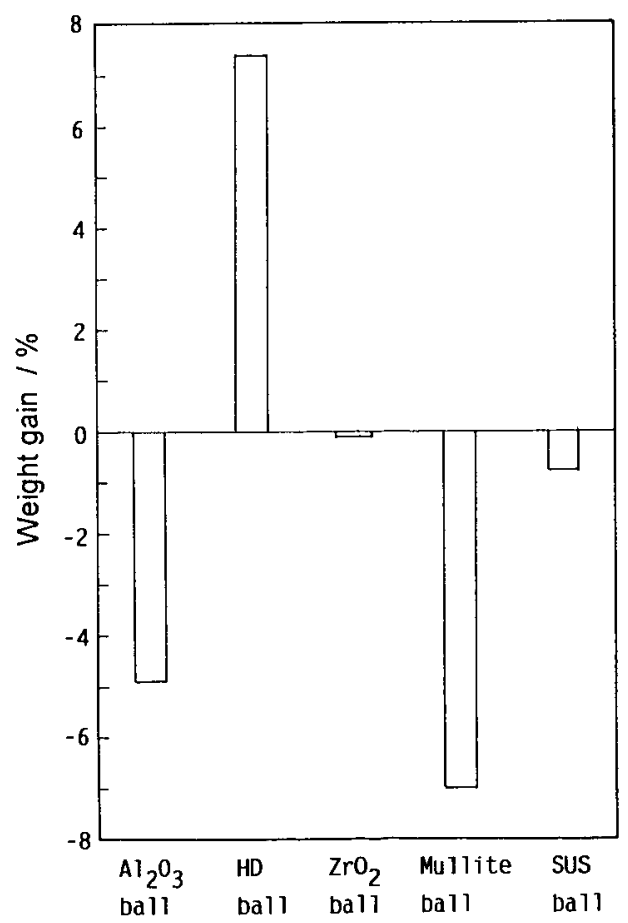

Fig.5 Weight gain of mechanical alloying ball milled for $720 \mathrm{ksec}$ with Ti-Si powder. 
Table3 Chemical composition of Ti-Si powder milled for $720 \mathrm{ksec}$ with $\mathrm{ZrO}_{2}$ balls.

\begin{tabular}{ccccc} 
& & \multicolumn{2}{c}{ (mass\%) } \\
& $\mathrm{Si}$ & $\mathrm{Ti}$ & $\mathrm{Fe}$ & $\mathrm{Zr}$ \\
\hline Ti-Si MA powder & 26.1 & 73.7 & 0.06 & 0.16
\end{tabular}

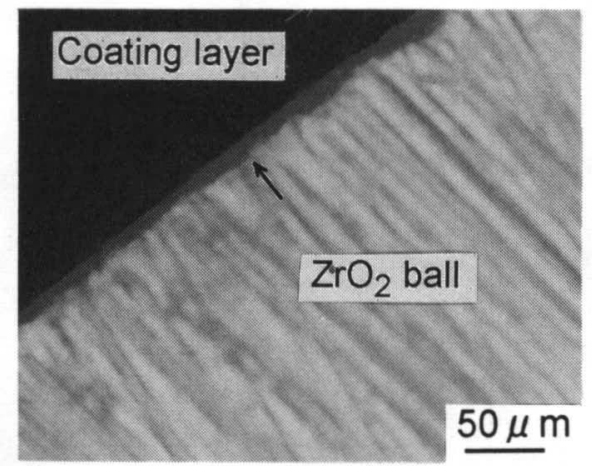

Fig.6 Microstructure of coating layer on the surface of $\mathrm{ZrO}_{2}$ ball milled for $720 \mathrm{ksec}$ with Ti-Si powder.

ルス鋼ボールでMAしたものよりやや凝集が多い，MA処 理前後における各MAポ-Nの重量変化をFig. 5に示す. ボールの耐磨耗性に関係すると考えられる硬度は，い ずれの材質とも不ル鎆より高く，なかでもアルミが 最も硬い。しかし，アルミナやムラ麻ールを用いた場合に はステンル鋼ボールを用いた場合より重量変化が大きい. MA処理後のボール表面に金属粉末が不均一に焼き付い

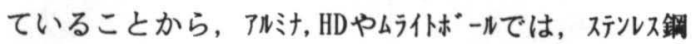
ボールと同じくボール表面にMA粉末が焼き付き，それが ある程度成長すると付着物がボー川材とともに剥離す る現象が生じているものと考えられる．HDボー川では ボール重量が增えているが, おそらく粉末の不均一な 付着が多いものと推察される.

ジルコアボールを用いた場合には、ボール表面が金属光 沢を有するほど均一な焼き付きが生じ, ボールの重量 変化は非常に小さい.ジルニアポールを用いて720ksec 間MA処理した $\mathrm{Ti}_{5} \mathrm{Si}_{3}$ 組成の粉末の化学分析を行うと, Table3のように, 容器からのFeやボールからのZrのコ 济ーションは非常に少ない. MA処理後のジルコニアボールを 切断して断面観察を行ってみると, Fig. 6に示すよ うにMAボール表面には10〜15 $\mu \mathrm{m}$ の均一なコーティング層

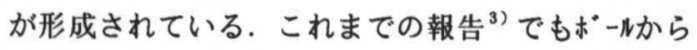
のコンタミネーションはMAのこく初期において急激に增加し， その後わずかに增加することが知られており，この

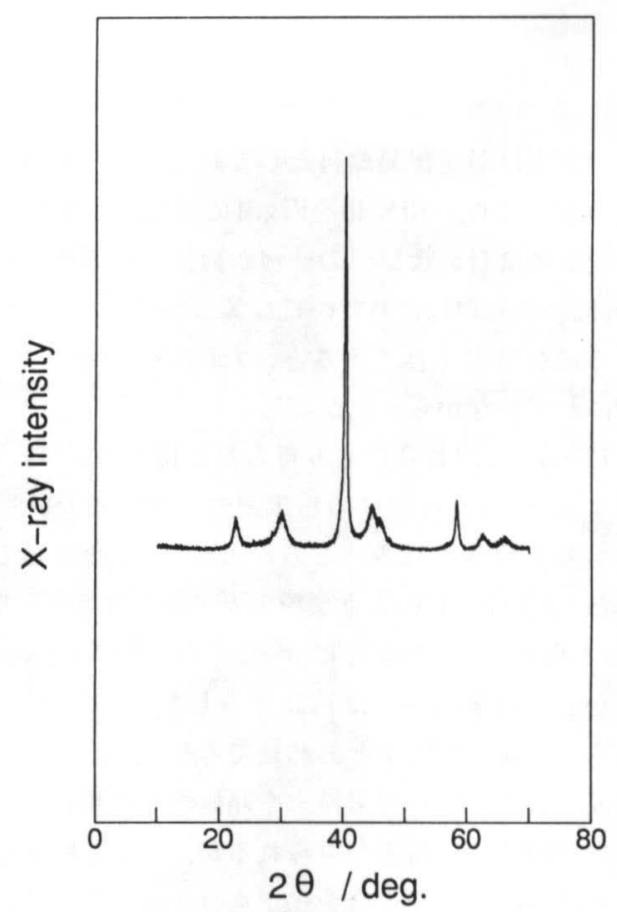

Fig.7 X-ray diffraction pattern of mechanically alloyed W-Si powder milled for $720 \mathrm{ksec}$ with $\mathrm{ZrO}_{2}$ balls.

コーティング層はMAのごく初期に形成された可能性が高 い、また、ジルコマアボールとコーティング層との結合力が大

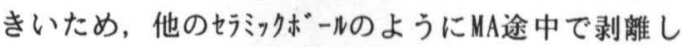
なかったものと考えられる，乾燥ジルコアリ゙ルと金属 粉末を用いてMA処理した場合に，スデルス鎆ボール表面 にコーティング層が形成されるこど)から，本コーティング層 もジルニアの有している酸素の易移動性によるものと 考えられる．また, Tiのように活性な金属元素を含 まない合金系をジルコニアボールを用いてMA処理してもボ ール表面にコーティッグ層が得られることから，MA粉末の 反応性にはあまり依存しないものと考えられる。な お，WA処理中にジルコニアがジルコ放まで還元されてこ の層全体を形成していることは考えられずボールと コーティング層との界面で酸素を介した結合が生じてい るものと推察される.

ジルコニボールを用いてMA処理した粉末では720ksec

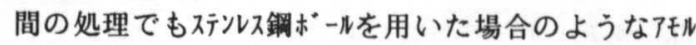
ファス状の粉末を得ることはできない，スデルス鋼ボールに 比へジッラアボーNの方が比重が小さいことから，MA時

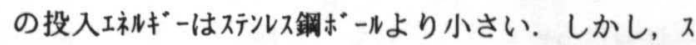


テッルス鎆ボールでは $360 \mathrm{ksec}$ 程度のMA処理においてすで にアモルアス状の粉末が得られることやジコニアより比重

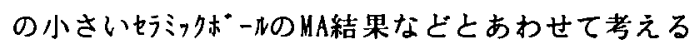
と、ジルコニアボール用いた720ksec間のHA処理でかな りプロードなX線回折パターンになってもよいと考えら れる. スデレス鋼术ールを用いたTi ${ }_{5} \mathrm{Si}_{3}$ のHA合成でてもルフ 状粉末が得られたのは, 容器やボールからのFeのコッタ 济ションが大きく奇与しているもの亡考えられる.

\section{3 その他の归仆系金属間化合物の合成}

最もMA処理中のコシタシネーションの少なかったジルニアボー

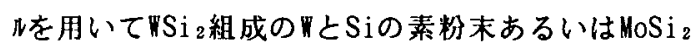
組成のMoとSiの素粉末を出発原料としてMA合成を行 った. $720 \mathrm{ksec}$ 間HA処理した政 2 組成の粉末の X線 回折パタ-ンをFig. 7に示す. MA処理による NSi $_{2}$ 相の合 成やアもル7ス状の粉末の合成はできていない，ただ， 『やSiのピークの愊はかなり広がっており，MA反応が 進行していることが考えられる. 今後さらに長時間 のMA処理を施すことによりHA反応が進行するものと 推察される.

MoSi 2 組成の素粉末を $720 \mathrm{ksec}$ 間のMA処理した場合 には, WSi ${ }_{2}$ の場合よりHA反応が進行し、Siのピークは ほほ消失し，やや幅の広がったHoのピークのみ観察さ れる。

\section{4 まとめ}

$\mathrm{Ti}$. Si の素粉末を出発原料として $\mathrm{Ti}_{5} \mathrm{Si}_{3}$ 組 成の金属間化合物をMA処理により合成した，合成さ
れた粉末のX線回折, SEM観察, 化学分析を行い, 生成相の同定やHA中のコンタタネーショッについて検討した. また，MA処理中のコンタミネーションの少ないボールの提案を 行い, WとSiあるいはHoとSiを出発原料とするWSi PHoSi ${ }_{2}$ 租成のシリサ仆系金属間化合物の合成を行っ た. その結果, 以下の結論が得られた.

(1)TiおよびSiの素粉末を出発原料としTi $5 \mathrm{Si}_{3}$ 組成 の金属關化合物をスデルス銅ボールを用いて合成すると， 得られる枌末は阮》7ス状である.しかし、このアモル 乃ス化にはボールからのFeのコンダネーションが寄与している。 （2ジルニアボールを用いるとMA中のコンタミネーションは少なく なる。これは，MA粉末による均一なコーティング層がジル コニアポー情面に形成されることに起因している。

（3）素枌末を出発原料として、コンタネネーショの少ないま

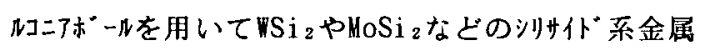
間化合物のHA合成を試みたが, $720 \mathrm{ksec}$ 間のHA処理 では十分に反応が進行しない。

\section{文 献}

1)山崎徹, 荻野喜清, 森下和彦, 福岡清人, 阿藤敏 行, 庄野安彦: 粉体および粉末冶金, 40(1993), 943. 2)小林器三, 高柳猛, 三輪謙治: 粉体および粉末治 金, 39(1992), 539

3)小林慶三, 高楖猛, 三輪謙治: 粉体および粉末冶 金, 40(1993), 62

4)小林度三，三輸謙治，高楖猛，大中逸雄: 粉体お よび粉末冶金, 40(1993), 955 